$\underline{\text { Avicenna Journal of Nursing and Midwifery Care - ISSN 2676-5748 }}$

\title{
The Effect of Concurrent Training on Serum Androgens Levels and Sexual Function in Menopausal Women
}

\author{
Mohammad Parastesh $^{1 *(D)}$ Zahra Mohseni $^{2}$ (D), Esfandiar Khosravi Zadeh ${ }^{3}$ (D), Abbas Saremi $^{4}$ (D)
}

1. Assistant professor, Faculty of Sport Sciences, Department of Sports Physiology, Arak University, Arak, Iran

2. M.Sc in Exercise Physiology, Department of Sports Physiology, Arak University, Arak, Iran

3. Associate Professor, Faculty of Sport Sciences, Department of Sports Management, Arak University, Arak, Iran

4. Associate Professor, Faculty of Sport Sciences, Department of Sports Physiology and Pathology, Arak University, Arak, Iran

Article Info

Received: 2021/02/22;

Accepted: 2021/09/04;

Published Online: 2021/12/21

10.30699/ajnmc.29.4.292

Original Article

Use your device to scan and read the article online

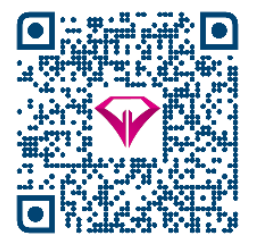

\section{ABSTRACT}

Introduction: Women's sexual function decreases during menopause, which in turn reduces their quality of life. Some studies have suggested that physical activity is associated with increased serum levels of androgens and improved sexual function. The aim of this study was to investigate the effect of concurrent training on serum androgens levels and sexual function in postmenopausal women.

Methods: The study was performed quasi-experimentally. The statistical sample of this study consisted of 30 postmenopausal women with an average weight of $65.1 \pm 5.4 \mathrm{~kg}$. Subjects were randomly divided into two groups of simultaneous training and control. The training group performed 8 weeks of concurrent training. Serum levels of dehydroepiandrosterone, testosterone and sexual function were measured 48 hours before and after training. Data were analyzed using SPSS 23 statistical software at a significance level of 0.05 .

Results: Concurrent training in the experimental group significantly increased serum testosterone levels compared to the control group $(P=0.042)$. Although concurrent training increased the serum level of dehydroepiandrosterone in the experimental group, but this value was not significant $(P=0.396)$. Concurrent training also increased sexual function in the areas of desire $(P=0.035)$, marital satisfaction $(P=0.002)$ and total scores $(P=0.047)$ in the concurrent training group compared to the control group.

Conclusion: In general, based on our findings, it seems that concurrent training improves sexual function in postmenopausal women by increasing serum testosterone levels.

Keywords: Menopause, Sexual development, Androgen, Testosterone, Dehydroepiandrosterone, Training 


\section{تأثير تمرين همزمان استقامتى و مقاومتى بر سطوح آندروزنها و عملكرد جنسى زنان يائسه

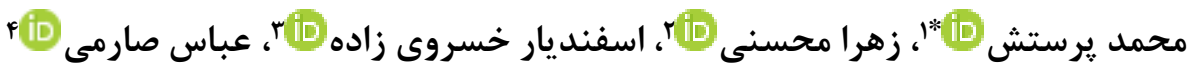

I. استاديار فيزيولوزى ورزشى، دانشكده علوم ورزشى، دانشگاه اراك، اراك، ايران

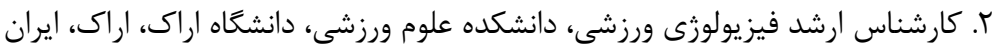

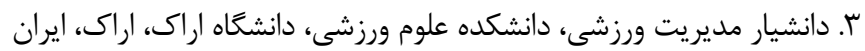

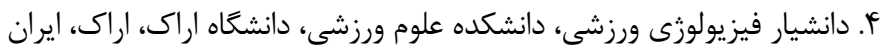

\begin{tabular}{|c|c|}
\hline "جكيده & اطلاعات مقاله \\
\hline 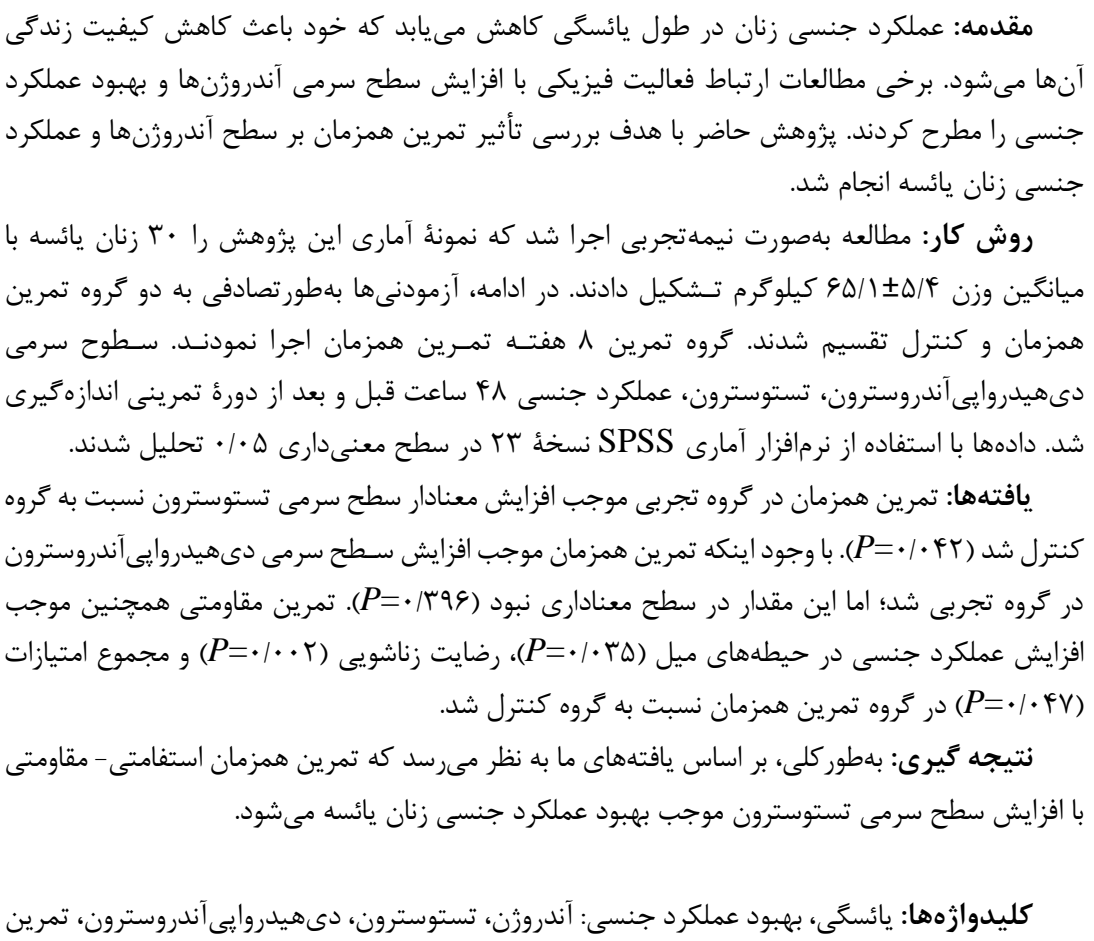 & 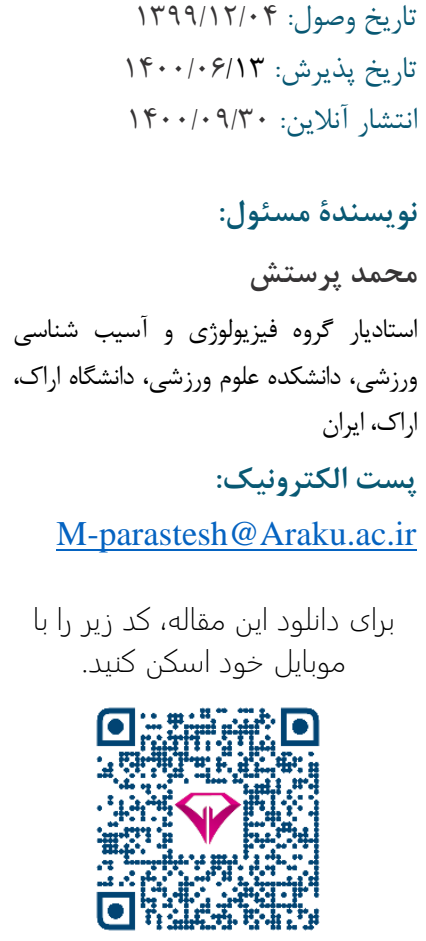 \\
\hline
\end{tabular}

آن در سنين · r تا • ب سالكى است (r). هورمون تستوسترون مهرمترين آندروزن است كه در زنان، در سنين قبل از يائسگى استى

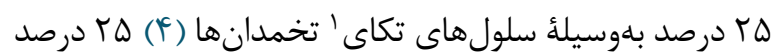
باهوسيله قشر غدد فوق كليوى و تقريباً ••ه درصد بقيه تستوسترون در خون، از تبديل محيطى هورمونهاى

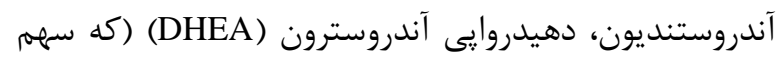
غده فوق كليوى • V درصد تا • • درصد و بقيه سهمم تخمدان

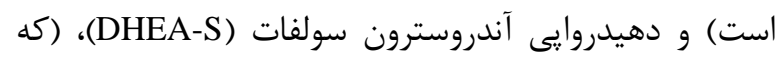
تقريباً هو تا . ا درصد آن از غدد فوق كليوى ترشح مىشود)،
يائسگى، يديدهاى كاملاً طبيعى و در واقع، نقطهاى از حيات يك زن است كه بهدليل كاهش فعاليت تخمدانها و كمبود استروزن، دورههاى قائدگى به يايان مىرسد و به اتمام

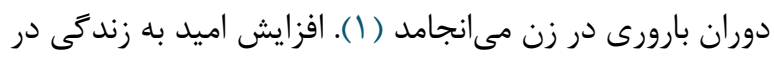
كشورها موجب شده تا زنان نيمى از عمر خود را دور در حالت

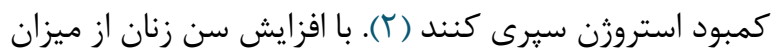

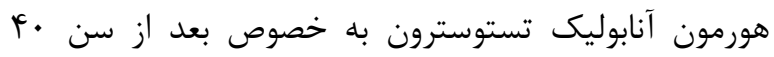

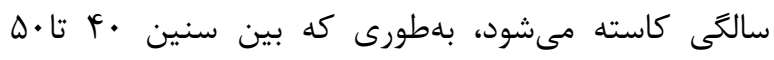
سالگى، سطح سرمى تستوسترون بهطور تقريبى، نصف مقدار

${ }^{1}$ Ovarian follicles 
در زير صدك ·ل و نمره پايين حوزههاى مختلف عملكرد جنسى در جمعيت مشابه استراليايى پِيدا شد (9 (1). با اين حال، در كزارش ديخرى بيشتر زنان با سطوح بايين DHEAS، عملكرد جنسى پايينى را كزارش نكردند (•) (Y). از طرفى تمرينات ورزش مىتواند از طريق جند بيومكانيسم مختلف موجب بهبود فعاليتهاى جنسى زنان

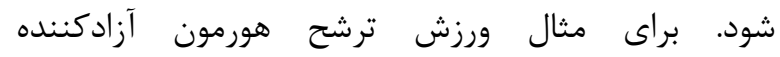
كورتيكوترويين (CRH) را تحريك مى كند و افزايش اين هورمون به ترشح بيشتر ACTH و اندورفين مىانجامد (Iال).

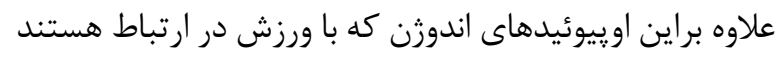

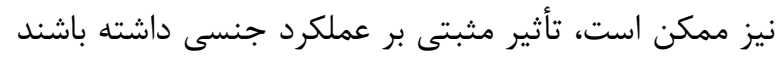

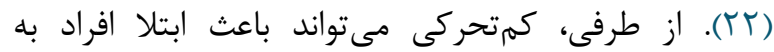

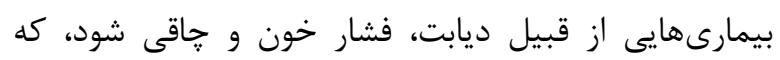

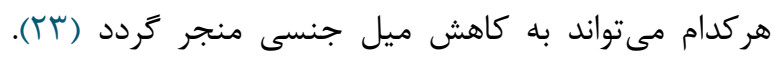
مطالعات نشان دادهاند كه تمرينات مقاومتى مىتواند سطوح

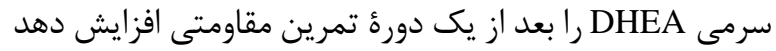
(TY) تمرين مقاومتى براى اختلالات عملكرد جنسى زنان انان يائسه

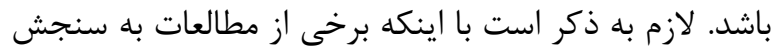

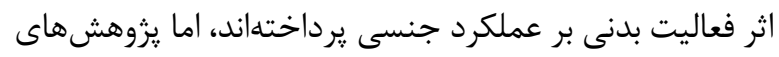

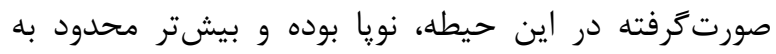
نمونههايى با بيمارىهاى خاص است. افزايش آندروزنها در درائر

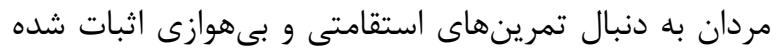

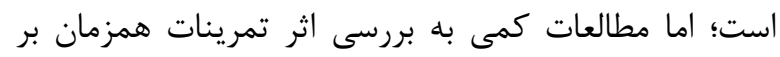

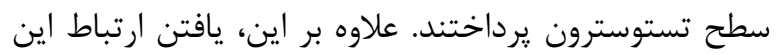

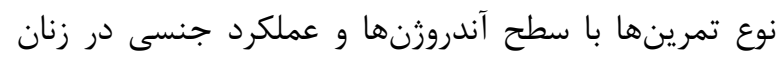

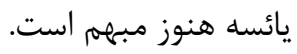
با توجه به مطالعات كذشته اختلالات عملكرد جنسى در الئه زنان يائسه به وضوح به اثبات رسيده است از طرفى به نظر

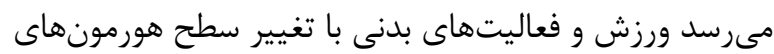

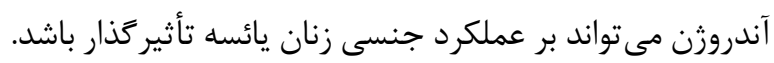
همجنين به نظر مىرسد، اثر تمرينات همزمان مقاومتى استقامتى بر اين دو متغير تاكنون بررسى نشده است. هدف

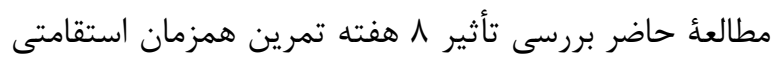

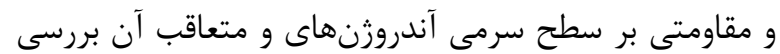

$$
\text { عملكرد جنسى زنان يائسه است. }
$$

\footnotetext{
${ }^{2}$ Dehydroepiandrosterone sulfate
}

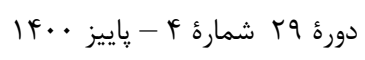

به وجود مى آيد (ه). در سنين بعد از يائسكى، تخمدانها منبع

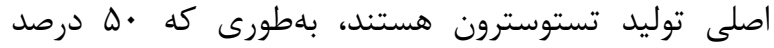
بهوسيلة تخمدانها، • ا درصد بلوسيلة قشر غدد فوق كليوى

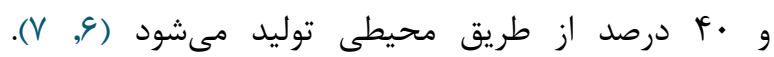
دىهيدروايى آندروسترون (DHEA) فراوانترين هورمون

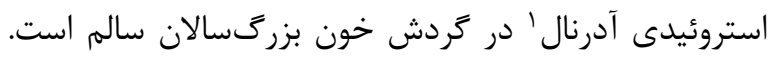

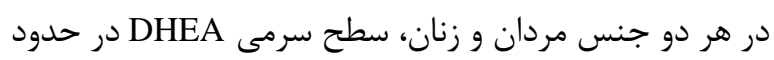

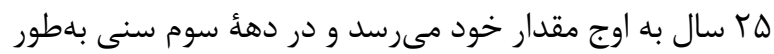
ييوسته كاهش مىيابد (^). همجنين كاهش سطوح سرمى

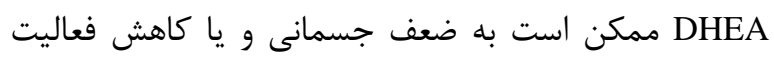

بدنى مرتبط باشد (9). عملكرد جنسى بخشى از زندكى و رفتار انسانى است و

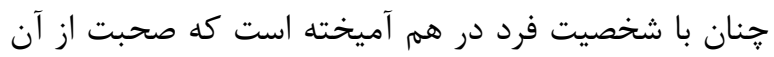

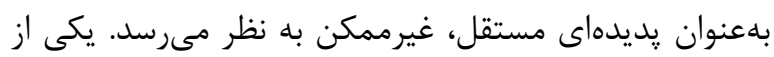
نكرانىهاى زنان در سنين يائسكى كاهش عملكرد جنسى آنها است. بر اساس مطالعههاى مبتنى بر جامعه، شيوع اختلال

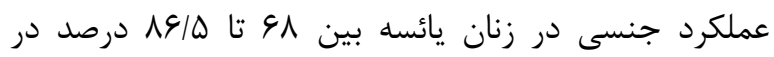
كشورهاى مختلف ذكرشده است (• (). در مطالعهاى در كشور ايران مشخص مى گردد كه دو سوم زنان يائسه (هأ تا هو ساله)

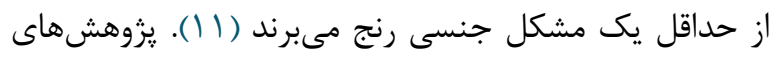
متعدد نشان مىدهد كه هورمونهاى جنسى ئسى (استروزن، آندروزنها و حتى يروزسترون) مغز را براى پاسخ التهابى به انكَيزهاى جنسى از طريق القاى شرايط عصبى - شيميايى

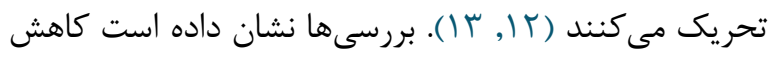
انگيزهٔ جنسى، برانگيختىى جنسى، لغزندهسازى وازثن و

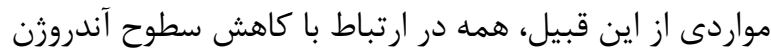

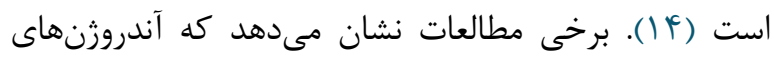
درونزا يا آندروزنهاى تجويزشده براى درمان، بهطور بالقوه

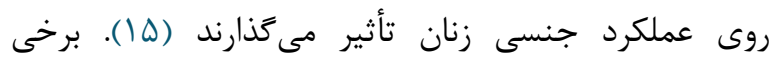

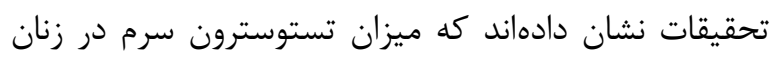

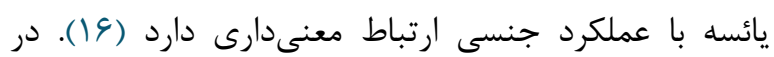
حاليكه در مطالعات ديكر هيج ارتباطى بين سطح تستوسترون

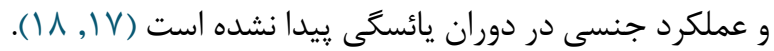

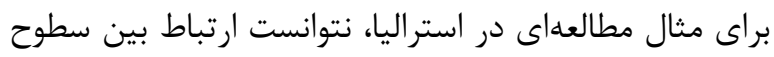

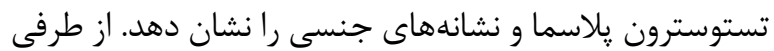
ارتباطى بين سطوح دهيدروايى آندروسترون سولفات` پِّاسما

${ }^{1}$ Circulating adrenal steroid hormone مجله مراقبت يرستارى و مامايى ابنسينا 
از حركات كششى، دويدن نرم به همراه جندين حركت ساده

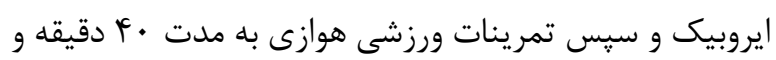

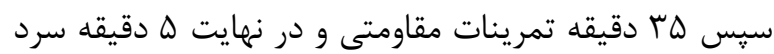
كردن شامل حر كات كششى انجام شد.

\section{ارزيابى عملكرد جنسى}

در اين مطالعه از يرسشنامة شاخص عملكرد جنسى زنان

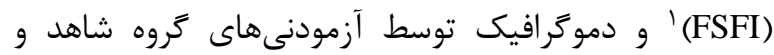
مداخله، قبل اجراى يروتكل تمرينى و FF ساعت يس از آخرين

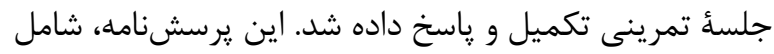

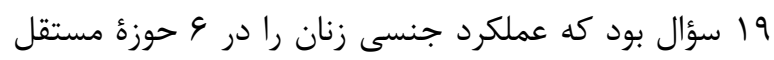

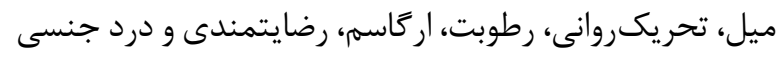

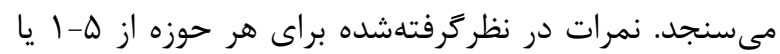
صفر است. نمره صفر به معنى عدم فعاليت جنسى در f هفته كذشته است. با جمع كردن نمرات شش حوزه باهم نمرة كل

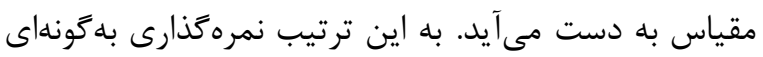
است كه نمره بيشتر، مبين كاركرد بهتر جنسى است. ضريب

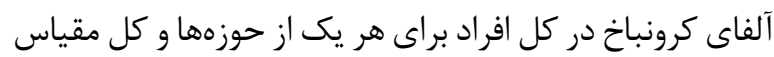

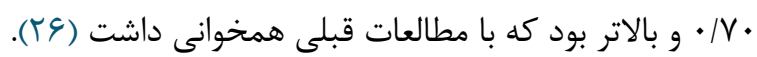

\section{اندازهَيرىهاى بيوشيميايى}

در اين مطالعه از سطح سرمى تستوسترون و دىهيدروايى نيى اندرسترون بهعنوان شاخصهاى اندروزن استفاده شد. اين دو هورمون مناسبترين و رايجترين شاخصهاى اندروزن در اندرون

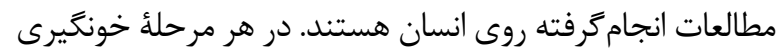

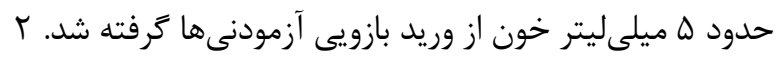
ميلىليتر از آن در لولههاى بدون ماده ضدانعقاد منتقل شد.

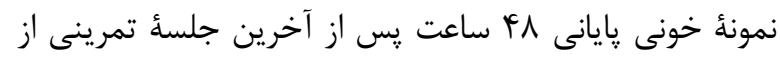

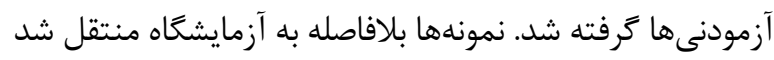
و در آزمايشگاه سرم خون توسط دستخاه سانتريفيوز (به مدت

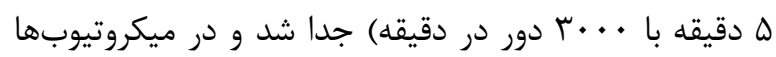

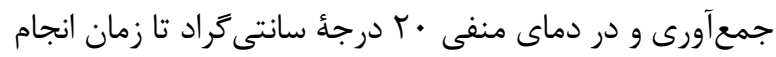
آناليز نتمهدارى شد. سطح سرمى تستوسترون با استفاده از

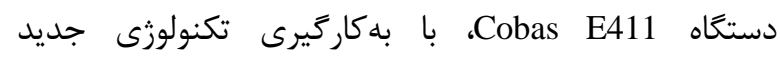
الكتروكمى لومينسانس ' (ECL) ساخت شركت Roche آلمان و

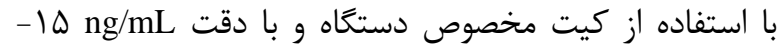

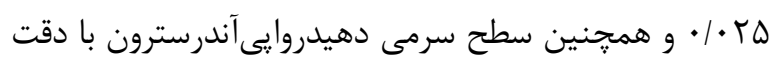
ng/mL
روش كار

يزوهش حاضر از نوع كارآزمايى كنترلشده تصادفى با طرح بيشآزمون- يسآزمون با دو گروه كنترل و مداخله است. اين

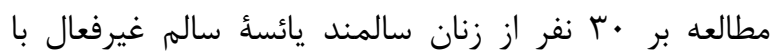

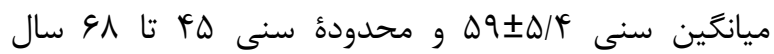
شهرستان كَليايگان انجام شد. معيارهاى ورود به مطالعه،

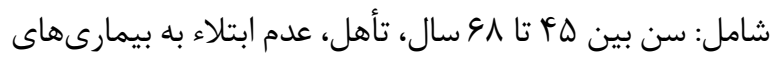
مزمن، عدم سابقهُ فعاليتبدنى منظم در يك سال قبل از از آغاز مطالعه و داشتن سطح سلامت عمومى جسمانى و روانى مبتلا نبودن به ديابت و نداشتن سابقه تخمدان يلى كيستيك بود؛ كه اين موارد با استفاده از يرسشنامه آمادگى براى شروع فعاليت ورزشى (PARQ) و يرسشنامه يِيشينأ يزشكى مورد ارزيابى قرار گرفت و معيارهاى خروج از مطالعه شامل: غيبت بيش از r جلسه و آسيب حين اجراى يروتكل تمرينى بود. يس از معرفى و تشريح اهداف يزوهش و مراحل و انتظارات يزوهشخر،

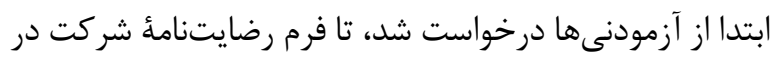
تحقيق را تكميل نمايند. نمونهها بهصورت مبتنى بر هدف، انتخاب و بهصورت تصادفى ساده قرعه كشى و به دو گروه شاهد

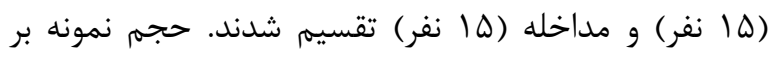
اساس مطالعات قبلى در اين زمينه و سيس بر اساس برآورد نرمافزار جى پاور (G Power) انجام يذيرفت كه مقدار اندازه اثر ه •/ إبا توجه به ميانخين و انحرافمعيار مطالعات قبلى (ييش

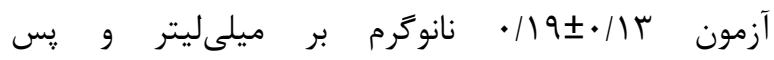

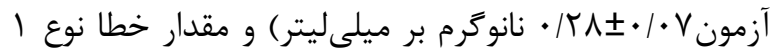

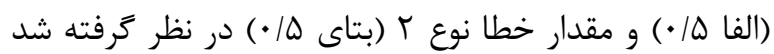

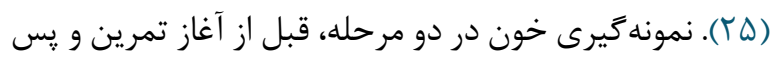

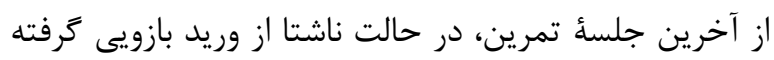
شد. همجنين نمونههاى گروه كنترل نيز در همين بازه زمانى Fرفته شد و نمونهُ دوم هم 1 هفته بعد، TF ساعت بعد از

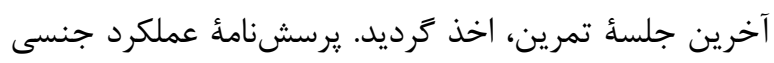

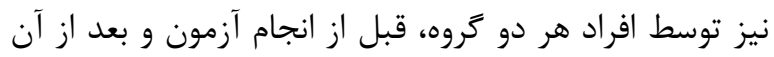

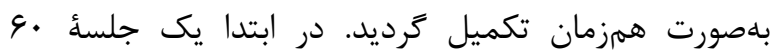
دقيقهاى آشناسازى با هدف يزوهش و آشنان آيى مختصرى با بان تمرينات براى تمام افراد شركت كننده انجام شد و سيس بر برنامئ تمرينات ورزشى به مدت 1 هفته، سه جلسه در هفته، هر جلسه • 9 دقيقه و شامل · ا دقيقه گرم كردن فعال با استفاده

${ }^{1}$ Female Sexual Function Index (FSFI)

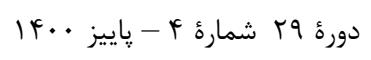

$$
\text { مجله مراقبت يرستارى و مامايى ابنسينا }
$$




\section{تمرينات استقامتى}

تمرينات هوازى به مدت • f دقيقه با • له درصد ضربانقلب هدف (THR) شروع و در جلسات انتهايى به • • درصد آن رسيد. معيار براى طراحى برنامه استقامتى ضربان قلب هدف بود. جهت اندازهيرى ضربان قلب هدف در ابتدا ضربان قلب استراحت آزمودنىها اندازهگيرى و سيس با استفاده از فرمول كارونن ضربان قلب هدف آزمودنى ها محاسبه شد. جهت تنظيمى شدت تمرين از ضربانسنج سينهاى يولارب استفاده شد. همجنين به آزمودنى ها نحوة اندازهذيرى ضربان قلب را آموزش داده و به هر شخص محدوده ضربان قلب هنگام تمرينات

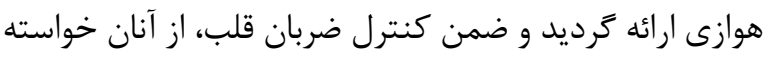
شد در محدوده ضربان قلب تعيينشده تمرينات خود را انجام دهند (YV). همجنين كلئُ تمرينات در سالن IV شهريور

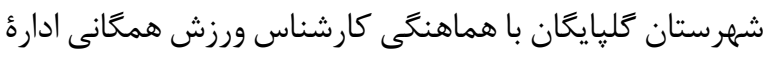
تربيت بدنى شهرستان گَليايعان انجام شد. ضربان قلب استراحت + (درصد شدت تمرينات × (ضربان قلب استراحت - ضربان قلب حداكثر)= ضربان قلب هدف

\section{تمرينات مقاومتى}

تمرينات مقاومتى بيشرونده با شدت • ه درصد يك تكرار

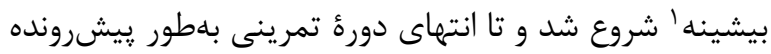
به •^ درصد 1RM افزايش يافت. ميزان 1RM به روش غيرمستقيم و با استفاده از فرمول برزيسكى بَ محاسبه كرديد. تمرينات مقاومتى شامل \& \& حركت بالاتنه (يرس سينه با دستخاه، سرشانه با دستخاه، جلو بازو با دستخاه و زير بغل لت

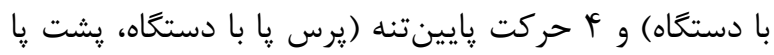
با دستخاه، جلو يا با دستخاه و ساق پا ايستاده با دستخاه) بود. ميزان وزنه هر دو هفته يك بار • ل درصد افزايش يافت. هر 1 ي حركت به تعداد ب ست و 9 الى 1 تكرار در هر ست انجام شده و بين هر ست • ب ثانيه استراحت و بين هر حركت ب دقيقه استراحت داده مىشود (YV).

جدول ا. برنامه تمرينات استقامتى - مقاومتى ييشرونده در طى ^ هفته تمرين

\section{هفته} هفته هidr

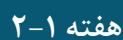

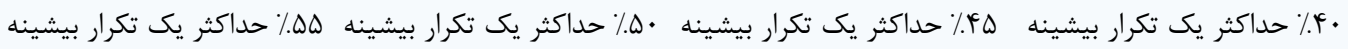

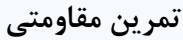

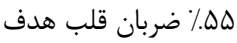

• • - مربان قلب هدف

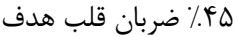

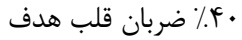

تمرين استقامتى

\section{تجزيهوتحليل آمارى}

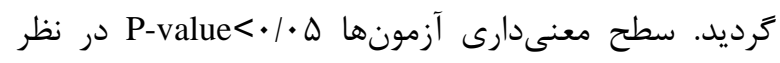
كرفته شده است.

\section{بافته ها}

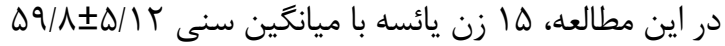

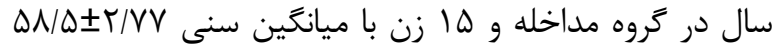
سال در گروه كنترل قرار كرفتند. تفاوت آمارى معنى درارى مدين بين سن و ساير اطلاعات دموگرافيك دو گروه كه در جدول ب ارائه شده است، وجود نداشت.
تجزيلوتحليل دادهها توسط نرمافزار SPSS نسخئ سب ( SPSS Inc., Chicago, Ill., USA ميانگين و انحراف استاندارد براى نمونههاى موجود در هر گروه

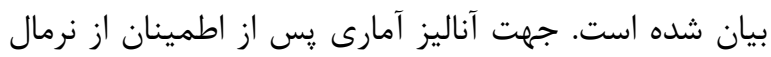

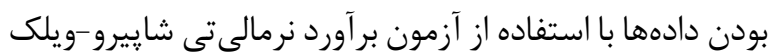

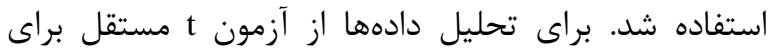
محاسبه نتايج قبل و بعد از مداخله در بين دو گروه و بلمنظور بررسى تفاوتهاى درون گروهى از آزمون t وابسته استفاده

${ }^{1}$ One Repetition Maximum or 1RM

${ }^{2}$ Brzycki formula
${ }^{3}$ Target heart rate or THR

${ }^{4}$ Polar heart rate sensor belt

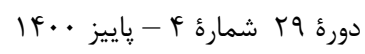

$$
\text { مجله مراقبت يرستارى و مامايى ابنسينا }
$$


جدول r. بررسى سطح آندروثن ها و شاخصهها تركيب بدنى در گروههاى مورد مطالعه

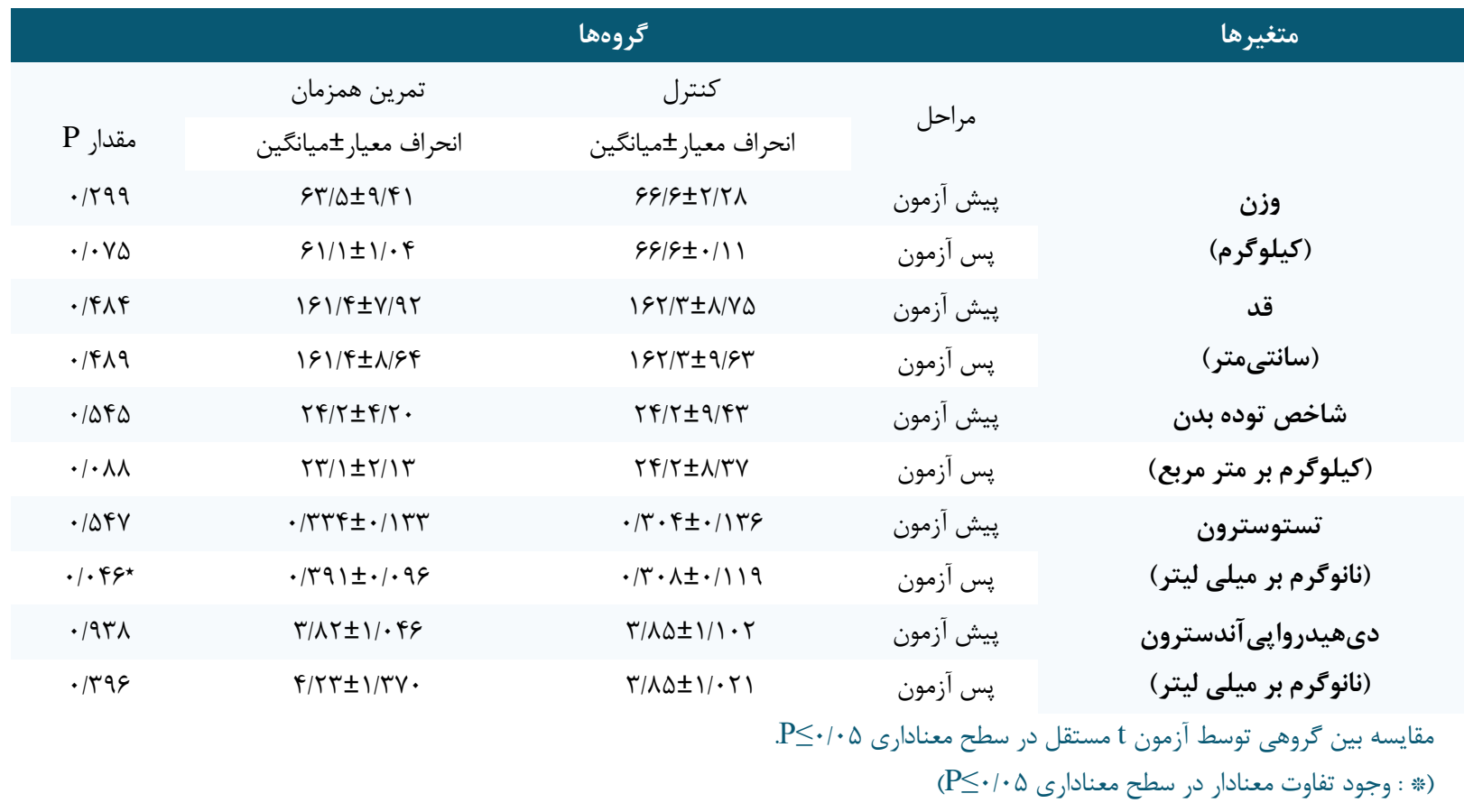

مداخله سطح DHEA نيز در گروه مداخله بهطور معنادارى

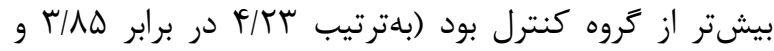
(P value $<\cdot 1 \cdot 0$

جدول r، عملكرد جنسى زنان دو گروه را قبل و بعد از مداخله، مقايسه مى كند. همانطور كه مشاهده مىشود، قبل از

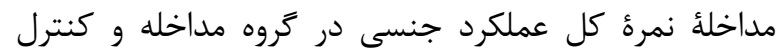

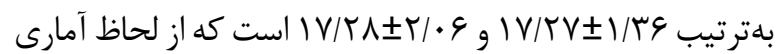
تفاوت معنادارى ندارند (ه • • • Palue مداخله، نمرة كل عملكرد جنسى در گروه مداخله، يس از انجام

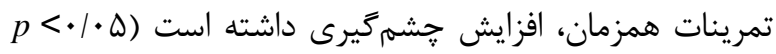
در حالى كه در زروه كنترل تغييرى مشاهده نشد (value

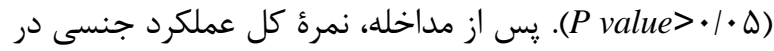

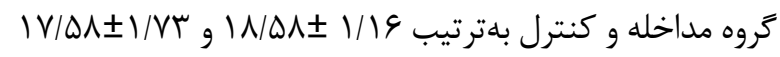
است كه اين تفاوت از لحاظ آمارى معنادار است (هـ •

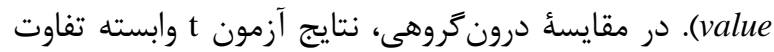

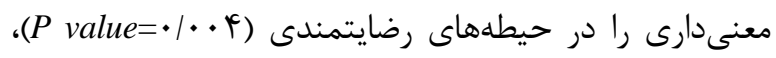

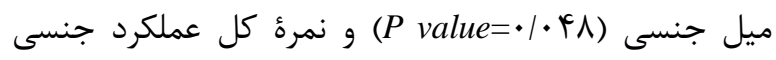
نشان داد. (P value= = / • r)
جدول r، مقايسهُ آندروزن هاى دو گروه مداخله و كنترل را در قبل و بعد از مداخله خلاصه مى كند. همان طور كه مشاهده مىشود، قبل از انجام دوره تمرينات استقامتى و مقاومتى،

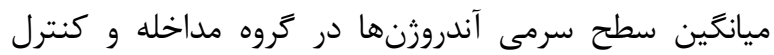

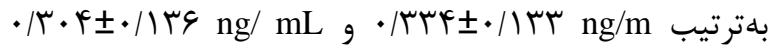
ng/ mL و برى تستوسترون و و

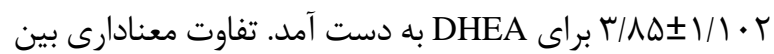
آندروزنهاى دو گروه در قبل از مداخله وجود نداشت (ه • • P (value). سطح سرمى تستوسترون بعد از مداخله، در مقايسه با

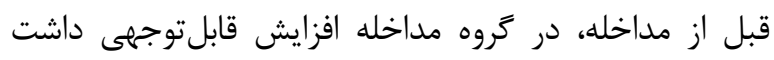
(P value • • (P)؛ اما در گروه كنترل تغيير قابل توجهى نداشت

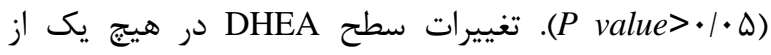

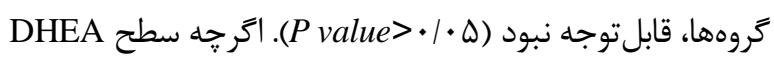
در گروه مداخله افزايش نشان مى دهد؛ اما در سطج معنادارى

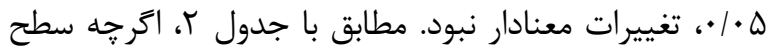
آندروزنهاى قبل از مداخله در دو گروه تفاوت معنادارى نداشتند؛ اما ڤِ از مداخله سطح تستوسترون در گروه مداخ مداخله بهطور معنادارى بيشتر از گروه كنترل بوده است (بهترتيب

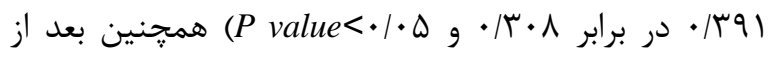


جدول ب • بررسى حيطههاى مختلف عملكرد جنسى در كَروهاى مورد مطالعه

\begin{tabular}{|c|c|c|c|c|}
\hline \multirow[b]{3}{*}{ مقدار P } & \multicolumn{3}{|c|}{ كروها } & \multirow[t]{3}{*}{ متغيرها } \\
\hline & تمرين همزمان & كنترل بى تمرين & & \\
\hline & انحراف معيار土ميانكَين & انحراف معيار „ميانگين & مراحل & \\
\hline . TAK & 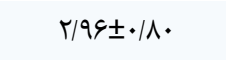 & $r / 9 \wedge \pm \cdot / 9 r$ & ي يیش آزمون & \multirow{4}{*}{$\begin{array}{c}\text { تحريك روانى } \\
\text { (Desire) } \\
\text { (Arousal) }\end{array}$} \\
\hline$\cdot / \cdot r \omega^{*}$ & $T / Y \Psi \pm \cdot \mid G V$ & T/VYE•/VA & گس آزمون & \\
\hline - IATT & $r / V Y \pm \cdot / F$. & $T / V \cdot \pm \cdot / \Delta \Delta$ & پيش آزمون & \\
\hline - IFE & T/Q४ $\pm \cdot / 4 \varnothing$ & $T / A T \pm \cdot / D \mid$ & ڤِ آزمون & \\
\hline . MAT & $r / l r \pm \cdot / r q$ & $r / \backslash \varepsilon \pm \cdot / r \Delta$ & קֶيش آزمون & \multirow{4}{*}{$\begin{array}{c}\text { رطوبت } \\
\text { (Lubrication) } \\
\text { اركاسم } \\
\text { (Orgasm) }\end{array}$} \\
\hline$\cdot / \lambda \cdot T$ & אس/•ע צא/ץ & $r / T T \pm \cdot / \Delta T$ & ڤِ آزمون & \\
\hline - NAT & 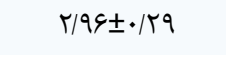 & $r / q r \pm \cdot / f \mid$ & يِيش آزمون & \\
\hline . & $r / \cdot 1 \pm \cdot / r q$ & $r / \cdot F \pm \cdot / R T$ & يس آزمون & \\
\hline . & rr/ & $T / M \pm \cdot / r V$ & پيش آزمون & \multirow{2}{*}{$\begin{array}{c}\text { رضايتمندى } \\
\text { (Satisfaction) }\end{array}$} \\
\hline$\cdot \cdot \cdot r^{*}$ & $r / \Delta F \pm \cdot / \Psi \Delta$ & $r / \varphi \pm \cdot / r$ & ڤِ آزمون & \\
\hline.$/ I T V$ & $T / Y Y \Psi \cdot \mid q V$ & $r / 99 \pm \cdot / \Delta \mid$ & קֶيش آزمون & \multirow{2}{*}{$\begin{array}{c}\text { درد جنسى } \\
\text { (Pain) }\end{array}$} \\
\hline ع| & $r / \Delta \varphi \pm \cdot / \Delta \Lambda$ & $r / r q \pm \cdot / V q$ & ֶس آزمون & \\
\hline.$/ 941$ & $\mid V / T V \pm I / T G$ & $\mid V / r \Lambda \pm 1 / \cdot 9$ & يِش آزمون & \multirow{2}{*}{ مجموع امتيازات } \\
\hline$\cdot / \cdot F V^{*}$ & $r \cdot|\Delta \Lambda \pm| / \mid \varepsilon$ & $\mid V / \Delta \Lambda \pm I / V r$ & پِ آزمون & \\
\hline
\end{tabular}

انجام تمرينات استقامتى و مقاومتى موجب افزايش جشم گير

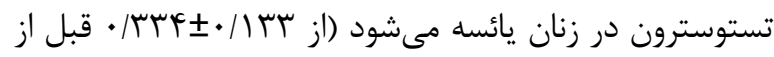

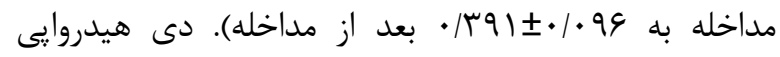
آندروسترون (DHEA) فراوانترين هورمون استروئيدى آدرنال در گردش خون بزرگسالان سالم است. در هر دو جنس مردان و زنان، سطح سرمى DHEA در حدود هr سالكَى به اوج مقدار

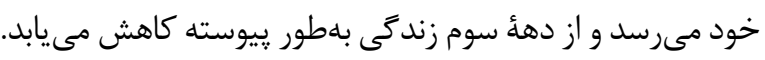
DHEA

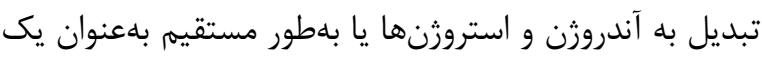

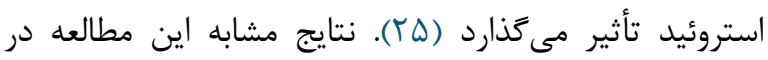
افزايش سطح آندروزنها با تمرينات ورزشى در جند مطالعه ديگر نيز مشاهده شده است. براى مثال، مطالعأ Eklund و و

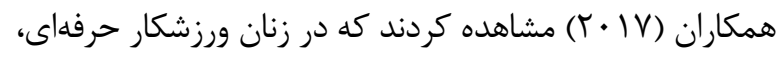

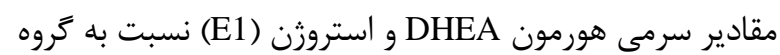

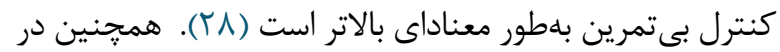

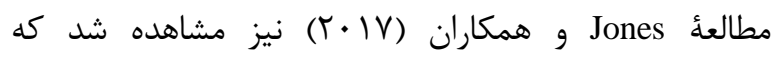
تمرينهاى مقاومتى و استقامتى موجب افزايش سطح سرمى همى
در اين مطالعه مشاهده شد كه 1 هفته تمرين همزمان استقامتى و مقاومتى در گرووه مداخله، باعث افزايش قابلتوجه سطح تستوسترون، نمره كل عملكرد جنسى و افزايش مىشود، هرجند از لحاظ آمارى معنادار نبود. در زيرمقياسهـا نيز مداخله باعث افزايش رضايتمندى و ميل جنسى در زروه مداخله شد؛ درحالى كه در رَوه كنترل تفاوت نتايج ناجيز بوده و در هيج حيطهاى تفاوت معنادارى در ييش آزمون و يس آزمون مشاهده نشد. در اين مطالعه از سطح سرمى تستوسترون و هيدروايى اندرسترون بهعنوان شاخصهاى آندروزن استفاده شد كد كه مناسبترين و رايجترين شاخصهاى آندروزن در مطالعات انجامًرفته روى انسان هستند. تستوسترون هورمون جنسى اصلى مردان بوده؛ اما در زنان نيز به ميزان كمتر وجود دارد. تأثير ورزشهاى استقامتى در افزايش غلظت يلاسمايى تستوسترون در مطالعات مختلف اثبات شده است. اين هورمون در زنان يائسه اهميتهاى فراوانى از جمله حفظ توده عضلانى و استخوان و بهبود عملكرد جنسى دارد. در اين مطالعه نشان داده شد كه

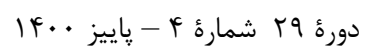




\section{نتيجه كيرى}

تمرينات همزمان استقامتى و مقاومتى باعث افزايش قابل

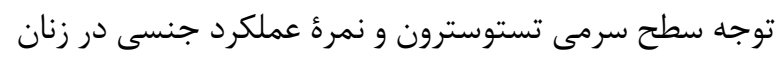

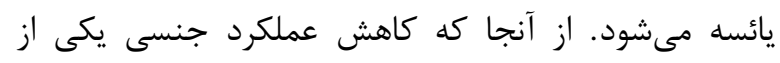

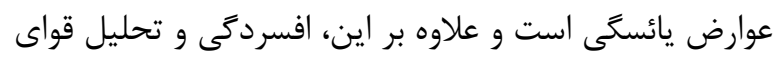

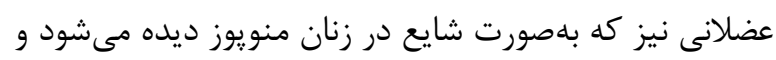

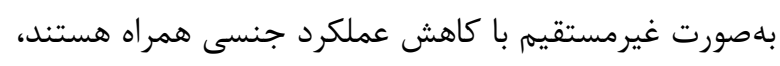

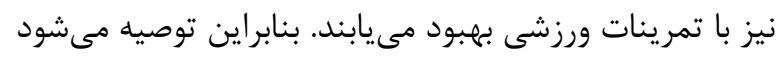
كه اقداماتى جهت تشويق و افزايش آكاهى زنات بنان يائسه از فورايد

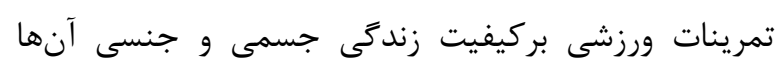
صورت كيرد.

\section{بيشنهادات}

با توجه به اين كه مطالعات كذشته و همجنين مطالعُ حاضر، جمعيت كوجكى را مورد بررسى قرار دادند و نتايج

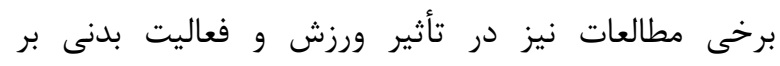

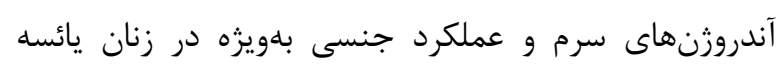
متناقض است توصيه مىشود كه مطالعات بيشترى برى خصوصاً مطالعات مرورى در اين زمينه انجام شود.

\section{سياسگزارى}

اين يروزه در قالب طرح يزوهشى با اعتبارات دانشخاه اراى

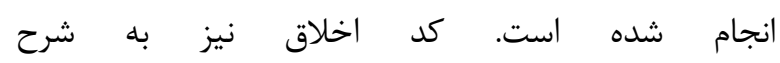
(IR.ARAKMU.REC.1399.172) يزوهشى دانشخاه علوم بزشكى اراى اخذ ترديده است. بدين

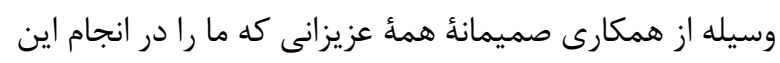

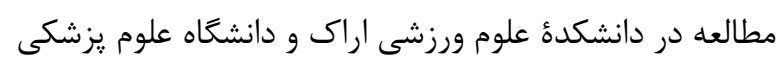
اراى يارى رساندند، سياسكزاريهم.

\section{تعارض در منافع}

نويسندكان هيجَّونه تعارضى در منافع اعلام نكردند.

$$
\text { منابع مالى ندارد. }
$$

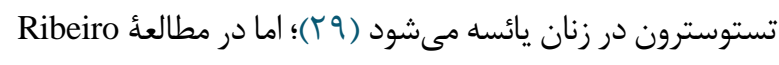

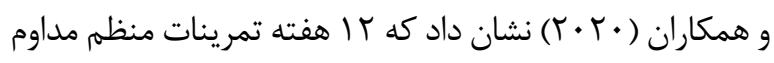
و تناوبى موجب كاهش آندروزنهاى سرمى (تستوسترون كل)

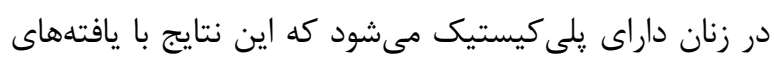

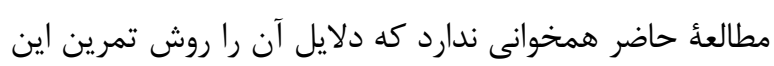
مطالعه مى توان نسبت داد (• (؟). عملكرد جنسى بر كيفت زندگى افراد تأثير بهسزايى دارد.

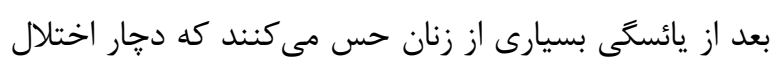

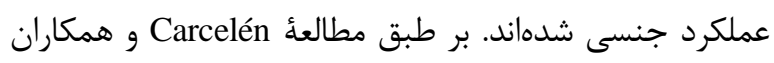

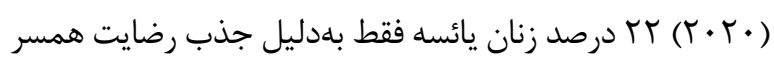

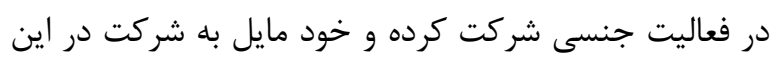

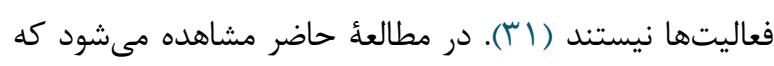

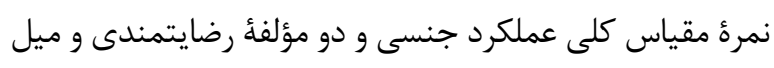

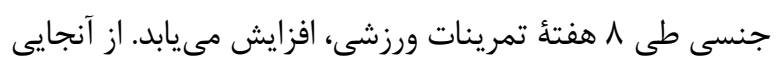

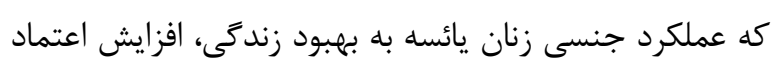

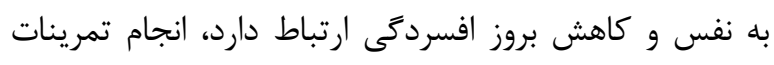

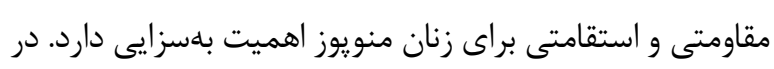

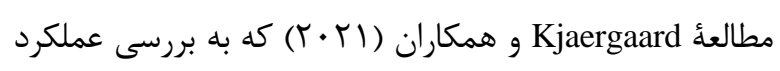

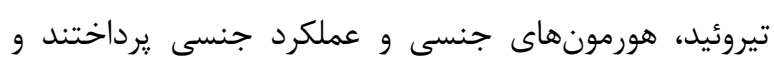

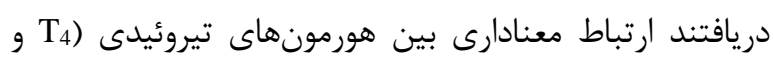

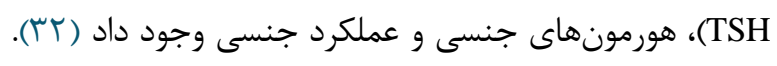

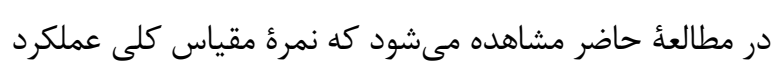

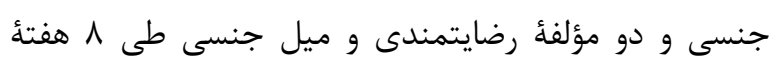

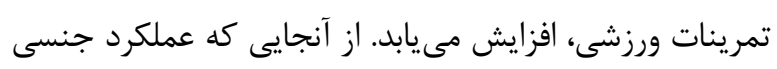

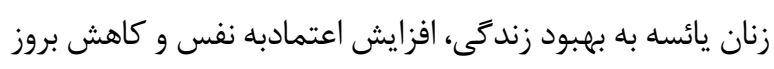

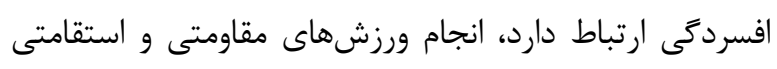

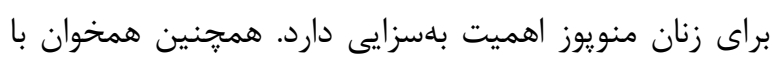

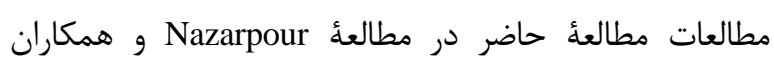

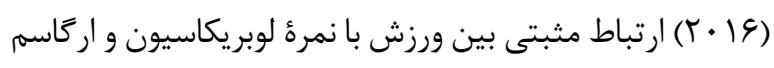

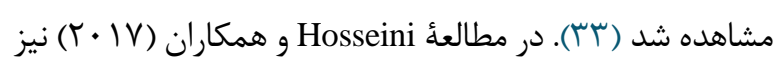
كه با هدف تعيين اثر تمرينات مقاومتى بر تصوير بدنى، اختلال

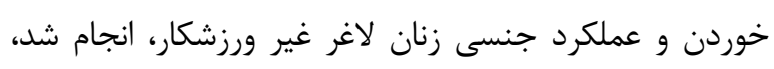

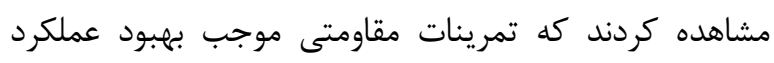

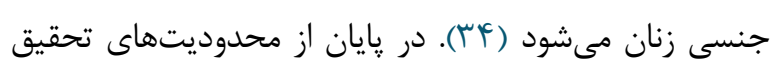

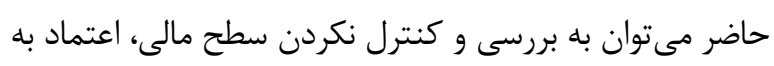

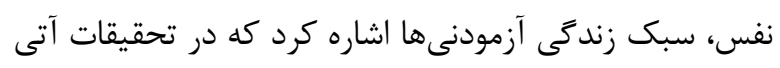

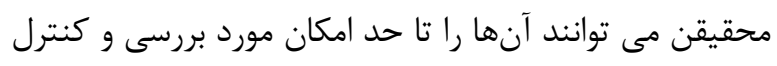
قرار دهند. 


\section{References}

1. Orsatti FL, Nahas EA, Maesta N, Nahas-Neto J, Burini RC. Plasma hormones, muscle mass and strength in resistance-trained postmenopausal women. Maturitas. 2008;59(4):394-404.

[DOI:10.1016/j.maturitas.2008.04.002] [PMID]

2. Mauvais-Jarvis F. Estrogen and androgen receptors: regulators of fuel homeostasis and emerging targets for diabetes and obesity. Trends Endocrinol Metab. 2011;22(1):24-33. [DOI:10.1016/j.tem.2010.10.002] [PMID] [PMCID]

3. Copeland JL, Chu SY, Tremblay MS. Aging, physical activity, and hormones in women-a review. J Aging Phys Act. 2004;12(1):101-16. [DOI:10.1123/japa.12.1.101] [PMID]

4. Nóbrega LH, Azevedo GD, Lima JG, Ferriani RA, Spritzer PM, Sá MF, et al. Analysis of testosterone pulsatility in women with ovulatory menstrual cycles. Arq Bras Endocrinol Metabol. 2009;53(8):1040-6. [DOI:10.1590/S0004-27302009000800020] [PMID]

5. Saad F, Gooren L. The role of testosterone in the metabolic syndrome: a review. J Steroid Biochem Molec Biol. 2009;114(1-2):40-3. [DOI:10.1016/j.jsbmb.2008.12.022] [PMID]

6. Braunstein GD. Androgen insufficiency in women. Growth Horm IGF Res. 2006;16:109-17. [DOI:10.1016/i.ghir.2006.03.009] [PMID]

7. Palacios S. Androgens and female sexual function. Maturitas. 2007;57(1):61-5.

[DOI:10.1016/j.maturitas.2007.02.014] [PMID]

8. Brahimaj A, Muka T, Kavousi M, Laven J, Dehghan A, Franco O. Serum dehydroepiandrosterone levels are associated with lower risk of type 2 diabetes: the Rotterdam Study. Diabetologia: clin Exp Metab. 2017;60(1):98-106. [DOI:10.1007/s00125-016-41368] [PMID] [PMCID]

9. Swiecicka A, Lunt M, Ahern T, O'Neill TW, Bartfai G, Casanueva FF, et al. Nonandrogenic anabolic hormones predict risk of frailty: European Male Ageing Study prospective data. J Clin Endocrinol Metab. 2017;102(8):2798-806. [DOI:10.1210/jc.2017-00090] [PMID] [PMCID]

10. Ambler DR, Bieber EJ, Diamond MP. Sexual function in elderly women: a review of current literature. Rev Obstet Gynecol. 2012;5(1):16.

11. Hashemi S, Tehrani FR, Simbar M, Abedini M, Bahreinian H, Gholami R. Evaluation of sexual attitude and sexual function in menopausal age; a population based cross-sectional study. Iran J Reprod Med. 2013;11(8):631.

12. Meston CM, Frohlich PF. The neurobiology of sexual function. Arch Gene Psychiatry. 2000;57(11):1012-30. [DOI:10.1001/archpsyc.57.11.1012] [PMID]
13. Giraldi A, Marson L, Nappi R, Pfaus J, Traish AM, Vardi Y, et al. Physiology of female sexual function: animal models. J Sex Med. 2004;1(3):237-53 [DOI:10.1111/j.1743-6109.04037.x] [PMID]

14. Schwenkhagen A. Hormonal changes in menopause and implications on sexual health. J Sex Med. 2007:4:220-6. 6109.2007.00448.x] [PMID]

15. Davison SL, Davis SR. Androgenic hormones and aging-the link with female sexual function. Horm Behav. 2011;59(5):745-53. [DOI:10.1016/i.yhbeh.2010.12.013] [PMID]

16. Turna B, Apaydin E, Semerci B, Altay B, Cikili N, Nazli O. Women with low libido: correlation of decreased androgen levels with female sexual function index. Int $\mathbf{J}$ Impot Res. 2005;17(2):148-53. [DOI:10.1038/sj.ijir.3901294] [PMID]

17. Gerber JR, Johnson JV, Bunn JY, O'Brien SL. A longitudinal study of the effects of free testosterone and other psychosocial variables on sexual function during the natural traverse of menopause. Fertilit Sterilit. 2005;83(3):643-8. [DOI:10.1016/i.fertnstert.2004.08.028] [PMID]

18. Dennerstein L, Alexander JL, Kotz K. The menopause and sexual functioning: a review of the populationbased studies. Annu Rev Sex Res. 2003;14(1):64-82.

19. Davis SR, Davison SL, Donath S, Bell RJ. Circulating androgen levels and self-reported sexual function in women. Jama. 2005;294(1):91-6. [DOI:10.1001/jama.294.1.91] [PMID]

20. Salonia A, Pontillo M, Nappi RE, Zanni G, Fabbri F, Scavini $\mathrm{M}$, et al. Menstrual cycle-related changes in circulating androgens in healthy women with selfreported normal sexual function. J Sex Med. 2008;5(4):854-63. [DOI:10.1111/j.17436109.2008.00791.x] [PMID]

21. Mastorakos G, Pavlatou M, Diamanti-Kandarakis E, Chrousos GP. Exercise and the stress system. Horm (Athens). 2005;4(2):73-89.

22. Bodnar RJ, Hadjimarkou MM. Endogenous opiates and behavior: 2002. Peptides. 2003;24(8):1241-302. [DOI:10.1016/i.peptides.2003.08.002] [PMID]

23. Di Stasi V, Verde N, Maseroli E, Scavello I, Cipriani S, Todisco T, et al. Female Sexual Dysfunction as a Warning Sign of Chronic Disease Development. Curr Sex Health Rep. 2019;11(4):307-19. [DOI:10.1007/s11930-019-00229-4]

24. Sato K, Iemitsu M, Matsutani K, Kurihara T, Hamaoka $\mathrm{T}$, Fujita S. Resistance training restores muscle sex steroid hormone steroidogenesis in older men. FASEB J. 2014;28(4):1891-7. [DOI:10.1096/fj.13-245480] [PMID]

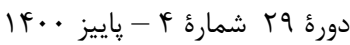


25. Yanagita I, Fujihara Y, Kitajima Y, Tajima M, Honda M, Kawajiri T, et al. A high serum cortisol/DHEA-S ratio is a risk factor for sarcopenia in elderly diabetic patients. J Endoc Soc. 2019;3(4):801-13 [DOI:10.1210/js.2018-00271] [PMID] [PMCID]

26. Maroufizadeh S, Riazi H, Lotfollahi H, Omani-Samani R, Amini P. The 6-item Female Sexual Function Index (FSFI-6): factor structure, reliability, and demographic correlates among infertile women in Iran. Middle East Fertilit Soc J. 2020;24(1):7. [DOI:10.1186/s43043-0190008-8]

27. Gibson AL, Wagner D, Heyward V. Advanced Fitness Assessment and Exercise Prescription, 8E: Hum kinet. 2018.

28. Eklund E, Berglund B, Labrie F, Carlström K, Ekström L, Hirschberg AL. Serum androgen profile and physical performance in women Olympic athletes. Br J Sports Med. 2017;51(17):1301-8. [DOI:10.1136/bjsports2017-097582] [PMID]

29. Jones TW, Howatson G, Russell M, French DN. Effects of strength and endurance exercise order on endocrine responses to concurrent training. Eur J Sport Sci. 2017;17(3):326-34. [DOI:10.1080/17461391.2016.1236148] [PMID]

30. Ribeiro VB, Kogure GS, Lopes IP, Silva RC, Pedroso DCC, de Melo AS, et al. Effects of continuous and intermittent aerobic physical training on hormonal and metabolic profile, and body composition in women with polycystic ovary syndrome: A randomized controlled trial. Clin Endocrinol. 2020;93(2):173-86. [DOI:10.1111/cen.14194] [PMID]

31. Carcelén-Fraile MdC, Aibar-Almazán A, MartínezAmat A, Cruz-Díaz D, Díaz-Mohedo E, RedecillasPeiró MT, et al. Effects of physical exercise on sexual function and quality of sexual life related to menopausal symptoms in peri-and postmenopausal women: A systematic review. Int Environ Res Public Health. 2020;17(8):2680. [PMID] [PMCID]

[DOI:10.3390/ijerph17082680]

32. Kjaergaard AD, Marouli E, Papadopoulou A, Deloukas $\mathrm{P}$, Kuś A, Sterenborg R, et al. Thyroid function, sex hormones and sexual function: a Mendelian randomization study. Eur J Epidemiol. 2021;36(3):33544. [DOI:10.1007/s10654-021-00721-z] [PMID]

33. Nazarpour S, Simbar M, Tehrani FR, Majd HA. Sexual function and exercise in postmenopausal women residing in Chalous and Nowshahr, Northern Iran. Iran Red Crescent Med J. 2016;18(5). [DOI:10.5812/ircmj.30120] [PMID] [PMCID]

34. HOSSEINI SM, BADAMI R, TAGHIAN F. Effect of strength exercise on physical appearance, eating disorder and sexual function in slender females. 2017.

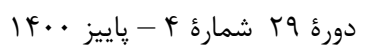

